\title{
Atrial natriuretic peptide modulates cystic fibrosis transmembrane conductance regulator chloride channel expression in rat proximal colon and human intestinal epithelial cells
}

\author{
H J Novaira, D S Ornellas, T M Ortiga-Carvalho, X M Zhang1, \\ J Souza-Menezes, S E Guggino ${ }^{1}$, W B Guggino ${ }^{2}$ and \\ M M Morales
}

Instituto de Biofísica Carlos Chagas Filho, Universidade Federal do Rio de Janeiro, CCS Bloco G, 21949-900 Rio de Janeiro, Brazil

${ }^{1}$ Department of Medicine-Gastroenterology, Johns Hopkins University School of Medicine, Baltimore, Maryland 21205, USA

${ }^{2}$ Department of Physiology, Johns Hopkins University School of Medicine, Baltimore, Maryland 21205, USA

(Requests for offprints should be addressed to M M Morales; Email: mmorales@biof.ufrj.br)

\begin{abstract}
The cystic fibrosis transmembrane conductance regulator (CFTR) is one of the most intensively investigated $\mathrm{Cl}^{-}$ channels. Different mutations in the CFTR gene cause the disease cystic fibrosis (CF). CFTR is expressed in the apical membrane of various epithelial cells including the intestine. The major organ affected in CF patients is the lung, but it also causes an important dysfunction of intestinal ion transport. The modulation of CFTR mRNA expression by atrial natriuretic peptide (ANP) was investigated in rat proximal colon and in human intestinal $\mathrm{CaCo}-2$ cells by $\mathrm{RNase}$ protection assay and semiquantitative reverse transcriptase PCR techniques. Groups of rats subjected to volume expansion or intravenous infusion
\end{abstract}

of synthetic ANP showed respective increases of 60 and $50 \%$ of CFTR mRNA expression in proximal colon. CFTR mRNA was also increased in cells treated with ANP, reaching a maximum effect at $10^{-9} \mathrm{M}$ ANP, probably via cGMP. ANP at $10^{-9} \mathrm{M}$ was also able to stimulate both the CFTR promoter region (by luciferase assay) and protein expression in CaCo-2 cells (by Western blot and immunoprecipitation/phosphorylation). These results suggested the involvement of ANP, a hormone involved with extracellular volume, in the expression of CFTR in rat proximal colon and $\mathrm{CaCo}-2$ intestinal cells. Journal of Endocrinology (2006) 189, 155-165

\section{Introduction}

The cystic fibrosis transmembrane conductance regulator (CFTR) is the most intensively investigated $\mathrm{Cl}^{-}$channel and it was the first anion channel to be identified by expression cloning (Riordan et al. 1989). CFTR gene emerged from the search for the cystic fibrosis (CF) locus (Nilius \& Droogmans 2003). It belongs to a family of proteins called traffic ATPases or ATP-binding cassette (ABC) transporters (Nilius \& Droogmans 2003). CF is characterized by reduction or abolishment of cell $\mathrm{Cl}^{-}$ secretion that leads to alterations in fluid and electrolyte epithelial transport causing abnormalities mainly of the respiratory and gastrointestinal systems (O'Loughlin et al. 1991, McCray et al. 1992).

Meconium ileus is observed in the gastrointestinal tract of approximately $10 \%$ of newborn CF patients, and obstructive gut disease is seen at later ages (Grubb \& Boucher 1999). In addition, in CFTR-knockout mice a phenotype was found that closely resembles the phenotype presented by CF patients, but the airway symptoms were not observed. In fact, most of these mice die from intestinal complications, which clearly indicates the crucial role of CFTR, especially in colonic $\mathrm{Cl}^{-}$secretion, and the absence of effective compensation (Snouwaert et al. 1992, Eckman et al. 1995).

CFTR protein has been localized on apical membranes of epithelial cells in both small and large intestines (Crawford et al. 1991, Gaillard et al. 1994). Functional analysis of cAMP-activated $\mathrm{Cl}^{-}$conductance and in situ hybridization studies showed the expression of CFTR in the intestinal cell population responsible for $\mathrm{Cl}^{-}$secretion mainly in crypt cells, where CFTR is highly expressed (Strong et al. 1994).

The CFTR not only functions as a $\mathrm{Cl}^{-}$channel, it can regulate other ion transporters such as outwardly rectifying chloride channels (ORCCs; Schwiebert et al. 1995) and the amiloride-sensitive epithelial sodium channel (ENaC; Stutts et al. 1995), and this regulation is also observed in the colon mucosal epithelium and/or colonocytes 
in culture (Ecke et al. 1996, Mall et al. 1999). After stimulation of wild-type CFTR by cAMP, amiloridesensitive $\mathrm{Na}^{+}$absorption is inhibited, while ORCCs are stimulated. For that reason, changes in the conductance and/or expression of CFTR can be relevant in $\mathrm{NaCl}$ transport and the consequent trans-epithelial fluid movement.

Hormonal modulation of ions transporters in the kidney and intestinal epithelia is well known to be important in extracellular volume regulation. Classical extracellular volume-regulating hormones such as aldosterone and glucocorticoids induce electrogenic absorption not only in the kidney but also in the distal colon (Grotjohann et al. 1999, Coric et al. 2004). The hormonal modulation of chloride channels in the apical membrane of epithelial cells was found in the kidney (Morales et al. 2001, Jentsch et al. 2002, Ornellas et al. 2002, Santos Ornellas et al. 2003), and also in the distal part of the intestine, particularly in the proximal and distal colon (Schroeder et al. 2000, Estevez et al. 2001, Kunzelmann \& Mall 2002).

Atrial natriuretic peptide (ANP) is a 28 -amino acid polypeptide hormone secreted mainly by the heart atria in response to atrial stretch and it is produced by changes in blood volume and/or arterial pressure (Dietz 1984, 1987). ANP was found to be synthesized in stomach and small and large intestine of humans and rats (Vuolteenaho et al. 1988, Ehrenreich et al. 1989, Gonzalez Bosc et al. 2000). This peptide is a classical inhibitor of $\mathrm{Na}^{+}$reabsorption, mainly in the cells of the renal collecting ducts (Maack 1996), but in the gastrointestinal tract it has an inhibitory effect on mineralocorticoid receptors in the proximal colon, inhibiting the $\mathrm{Na}^{+}$absorption induced by aldosterone (Schulman et al. 1996), probably via cGMP and protein kinase $G$ intracellular second messengers (Argenzio \& Armstrong 1993, Waldman et al. 1984). Furthermore, it is known that the conductance of $\mathrm{Cl}^{-}$ channels is effectively regulated by protein kinase $\mathrm{G}$ (Lin et al. 1992). Thus, it is reasonable to postulate that ANP can act on epithelial cells through its cyclase-couped receptor and, thereby, modulates $\mathrm{Cl}^{-}$channel conductance and/or expression.

The main purpose of this work was to increase our knowledge of CFTR chloride channel expression control in the gastrointestinal tract by studying its expression regulation in proximal colon of rats subjected to extracellular volume expansion or intravenous infusion of synthetic ANP. CFTR channel expression modulation by ANP was also investigated in human colon adenocarcinoma cells (CaCo-2 cells).

\section{Materials and Methods}

\section{Cell culture}

Human CaCo-2 cells were chosen for the present study because of their morphologic and functional characteristics, similar to normal human enterocyte cells, when reaching confluence in culture (Grasset et al. 1985). CaCo-2 cells were cultured in Dulbecco's modified Eagle's medium (DMEM) supplemented with 10\% fetal bovine serum (Gibco BRL), $25 \mathrm{mM}$ glucose, $2 \mathrm{mM}$ L-glutamine, $100 \mathrm{U} / \mathrm{ml}$ penicillin and $100 \mu \mathrm{g} / \mathrm{ml}$ streptomycin (Gibco BRL) at $37^{\circ} \mathrm{C}$ in a fully humidified atmosphere of $5 \% \mathrm{CO}_{2}$ in air. CaCo-2 cells were grown until they reached $90 \%$ of confluence, and then incubated with DMEM in the absence of fetal bovine serum for $12 \mathrm{~h}$, and treated with ANP $\left(10^{-11}, 10^{-10}, 10^{-9}, 10^{-8}\right.$ and $\left.10^{-6} \mathrm{M}\right)$ in DMEM without fetal bovine serum, at $37^{\circ} \mathrm{C}$ for $24 \mathrm{~h}$ on $35 \mathrm{~mm}$ tissue-culture dishes. As we shown in previous reports after $24 \mathrm{~h}$ we can see changes in mRNA expression in cells treated with different hormones (Morales et al. 2001, Santos Ornellas et al. 2003).

The ANP hormone was diluted in double-distilled water. To study ANP action via a secondary signaling pathway on CFTR mRNA expression, cells were incubated with $1 \mathrm{mM}$ cGMP, $5 \mu \mathrm{M}$ cGMP inhibitor (cGMPI; Chang et al. 1991, Sood et al. 1992) and $10^{-9}$ M ANP, divided into different groups: A, non-treated cells (NT); $\mathrm{B}$, cells treated with ANP; C, cells treated with ANP+cGMPI; D, cells treated with cGMP+cGMPI; E, cells treated with cGMP; F, cells treated with cGMPI; and G, cells treated with ANP+cGMP. Cells incubated only with DMEM without bovine fetal serum during $24 \mathrm{~h}$ were used and called the control NT group.

\section{Animal preparation}

The Ethics Committee of the Biophysics Institute, Federal University of Rio de Janeiro, previously approved all procedures and protocols using animals mentioned in this paper. Male adult Wistar rats (weight of 300-350 g) were kept in a room with controlled lighting (12 h light:12 h darkness; lights on at 08:00 h, off at 20:00 h) and temperature $\left(23-27^{\circ} \mathrm{C}\right)$. All groups had free access to food and tap water until the time of the experiment.

Rats subjected to volume expansion or continue i.v. infusions were anesthetized with an intraperitoneal injection of pentobarbital sodium $(50 \mathrm{mg} / \mathrm{kg})$ and $5 \mathrm{mg}$ of diazepam, and then the femoral vein was catheterized for extracellular-expansion and ANP infusion-experiments. Rats subjected to volume expansion were infused intravenously with $10 \mathrm{ml}$ of isotonic saline (0.9\%) for $5 \mathrm{~min}$ ( $2 \mathrm{ml} / \mathrm{min}$; Kato et al. 1986), and $1 \mathrm{~h}$ after the beginning of injection the rats were killed and proximal colon samples removed.

In the group of rats subjected to continuous i.v. infusion, synthetic ANP ( $\alpha$-atriopeptin, or rANP; Sigma) in $0.9 \% \mathrm{NaCl}$ was infused as a $4 \mu \mathrm{g} / \mathrm{kg}$ priming dose over a $2 \mathrm{~min}$ interval, followed by continuous i.v. infusion at $0.5 \mu \mathrm{g} / \mathrm{kg}$ per $\min (1.56 \mathrm{ml} /$ hour $)$ for $60 \mathrm{~min}$. After this procedure the animals were killed and the proximal colons removed. Control-group rats were infused intravenously with $0.9 \% \mathrm{NaCl}$ (at $1.56 \mathrm{ml} /$ hour; Dunn et al. 1986). 
Abdominal aorta and vena cava were sectioned in order to kill the animals. This procedure leads to a massive hemorrhage that quickly kills the animals. Then proximal colon samples were removed, rinsed with PBS solution and total RNA immediately extracted from tissues using Trizol ${ }^{\circledR}$ reagent $(\mathrm{Gibco} B R \mathrm{~L})$.

\section{Isolation of total RNA}

Total RNA was extracted from $\mathrm{CaCo}-2$ cell cultures and rat proximal colon tissues using Trizol ${ }^{\circledR}$ reagent, following the protocol suggested by the manufacturer. The isolated RNAs were treated with $1 \mathrm{U} / \mu \mathrm{l}$ RNase-free DNase I (Gibco BRL) for $30 \mathrm{~min}$ to eliminate contamination with genomic DNA. Autoclaved diethylpyrocarbonate-treated water was used to dissolve the RNA, which was quantified by spectrophotometric absorbance at $260 \mathrm{~nm}$.

\section{RNase protection assay (RPA)}

A human CFTR 247 bp segment (nucleotides 531-778) obtained through reverse transcriptase PCR (RT-PCR) was subcloned into pCR-Script $\mathrm{SK}(+)$. One microgram of this plasmid was linearized using NotI restriction enzyme. Following the Maxiscripit kit protocol (Ambion, Austin, TX, USA) templates were transcribed in vitro in the presence of T7 RNA polymerase, $\left[\alpha_{-}{ }^{32}\right.$ P]UTP (3000 $\mathrm{Ci} / \mathrm{mmol}$; NEN-Dupont, Boston, MA, USA) and nucleotides guanidine, adenosine, thiamine and cytosine, generating radiolabelled antisense RNA probes. All probes were evaluated with $10 \mu \mathrm{g}$ yeast tRNA in the presence and absence of RNase $A$ and $T_{1}$ following the RPAII kit protocol (Ambion). Total RNA $(30 \mu \mathrm{g})$ from CaCo-2 cells was mixed with radiolabelled antisense probe to CFTR $\left(1 \times 10^{5}\right.$ c.p.m./sample $)$ and pTRI- $\beta$-actin-125human $\left(1 \times 10^{5}\right.$ c.p.m./sample; Ambion), a human $\beta$-actin radiolabelled antisense probe to actin (127 bp) corresponding to nucleotides 853-979 of $\beta$-actin human sequence (an internal control), and hybridized at $45^{\circ} \mathrm{C}$ for $18 \mathrm{~h}$. Previous experiments were made to set optimal RNA quantities. These products were then treated with a mixture of RNase $A$ and $\mathrm{T}_{1}$ at $37{ }^{\circ} \mathrm{C}$ for $30 \mathrm{~min}$. The protected fragments were separated by electrophoresis on $8 \mathrm{M}$ urea gels containing $50 \mathrm{~g} / 1$ polyacrylamide. The samples were transferred to chromatography paper and exposed to X-ray films with an intensifying screen at $-70{ }^{\circ} \mathrm{C}$ for $24 \mathrm{~h}$. After the films had been developed the density of the bands corresponding to the expected sizes of the probes was analyzed by Scion Image Alpha $4 \cdot 0 \cdot 3 \cdot 2$ software (Scion Corporation, Frederick, MD, USA).

\section{$R T-P C R$}

Total RNA (250 ng) was used to prepare first-strand cDNA. These total RNAs were first primed with
oligo(dT) primer and then reverse-transcribed with SuperScript ${ }^{\mathrm{TM}}$ (Gibco BRL) at $37^{\circ} \mathrm{C}$ for $60 \mathrm{~min}$. The negative control corresponded to a $250 \mathrm{ng}$ aliquot of total RNA used for cDNA synthesis in the absence of the RT enzyme, and was called $\mathrm{RT}(-)$. The cDNA synthesis reaction was interrupted by DNA extraction using a mixture containing phenol, chloroform and isoamyl alcohol (PCI-25:24:1, vol/vol), and then precipitated with $100 \%$ ethanol and ammonium acetate $(7 \cdot 5 \mathrm{M})$ for $24 \mathrm{~h}$ at $-20{ }^{\circ} \mathrm{C}$. Finally, the cDNA was re-suspended in $5 \mu \mathrm{l}$ of deionized water.

In the PCR reaction, $c D N A s$ were used in the presence of $2 \cdot 5$ units Taq polymerase (Gibco BRL), $0 \cdot 2 \mu \mathrm{M}$ of each primer (CFTR and $\beta$-actin), $0 \cdot 2 \mu \mathrm{M}$ of each nucleotide and commercial buffer (Gibco BRL) containing $1.5 \mathrm{mM}$ $\mathrm{MgCl}_{2}$. PCR was performed under the following conditions: initial denaturation at $94{ }^{\circ} \mathrm{C}$ for $4 \mathrm{~min}$, followed by 36 cycles of denaturation $\left(94^{\circ} \mathrm{C}, 1 \mathrm{~min}\right)$, annealing $\left(58^{\circ} \mathrm{C}, 1 \mathrm{~min}\right)$ and extension $\left(72^{\circ} \mathrm{C}, 1 \mathrm{~min}\right)$. The reaction was concluded with an extension for $10 \mathrm{~min}$ at $72{ }^{\circ} \mathrm{C}$. Preliminary experiments were done to set the optimal conditions for the RT-PCR. The primers used in CFTR $\mathrm{PCR}$ reactions in $\mathrm{CaCo}-2$ cells samples were 5 '-CAC GCT TCA GGC ACG AAG-3' and $3^{\prime}$-GCA GAG GTG GCT GCT TC-5', which produced a DNA segment of $268 \mathrm{bp}$. As an internal control, human $\beta$-actin primers 5'-GTT GCT ATC CAG GCT GTG-3' and 3'-CAC TGT GTT GGC GTA CAG-5' were used, which produced a segment of $485 \mathrm{bp}$.

The primers used for the CFTR PCR reactions in rat proximal colon samples were $5^{\prime}$-CTG CCA TTG CTG GAG TTG-3' and 5'-GCA GCC ATC CTC TAG AAC-3', which produced a DNA segment of $615 \mathrm{bp}$. As an internal control the rat GAPDH primers $5^{\prime}-\mathrm{GTC}$ TTC ACC ACC ATG GAG-3' and 3'-CAT GAC AAC TTT GGC ATC-5' were also used, which produced a segment of $211 \mathrm{bp}$. For RT-PCR of natriuretic peptide receptors (NPRs) in CaCo-2 cells we used the following human primers: (i) human NPR type A (NPR-A) primers 5'-GCA TTG AGC TGA CAC GAA AA-3' and 5'-CCT TGA CGA TGT CAT TGG TG-3', which produced a segment of $219 \mathrm{bp}$, (ii) human NPR type B (NPR-B) primers 5'-AGC GCT GAA GAT CCA TGT CT-3' and 5'-GGA GTC CAG GAG GTC CTT TC-3', which produced a segment of $155 \mathrm{bp}$ and (iii) human NPR type C (NPR-C) primers 5'-GGA GAC CGA TAT GGG GAT TT-3' and 5'-CAC TGC CGA TTC TTC TAG GC-3', which produced a segment of $222 \mathrm{bp}$.

The identies of amplified products was confirmed by determination of molecular size on agarose gel electrophoresis $(1.5 \%$ agarose in buffer containing $40 \mathrm{mM}$ Tris/ acetate and $1 \mathrm{mM}$ EDTA) and visualized by ethidium bromide staining $(0.5 \mu \mathrm{g} / \mathrm{ml})$ under ultraviolet light. The CFTR, $\beta$-actin and GAPDH bands from samples were analyzed by densitometry (Scion Image Alpha $4 \cdot 0 \cdot 3 \cdot 2$ ). Expression was normalized by dividing the CFTR values 
by the corresponding internal control values $(\beta$-actin or GAPDH) amplified in the same reaction tube.

\section{Immunoprecipitation and phosphorylation of CFTR}

Biochemical analysis of CFTR expression and glycosylation was performed by immunoprecipitation with antiCFTR antibodies followed by in vitro phosphorylation using protein kinase A (PKA) and $\left[\gamma_{-}{ }^{32} \mathrm{P}\right] \mathrm{ATP}$. The procedures were described previously (Cheng et al. 1990, Denning et al. 1992, Gregory et al. 1990). Briefly, cells grown under the indicated conditions were rinsed twice with PBS (Sigma) and scraped into lysis buffer $(20 \mathrm{mM}$ HEPES, pH 7.0, $150 \mathrm{mM} \mathrm{NaCl}, 2 \mathrm{mM}$ EDTA and 1\% Nonidet P40) containing $1 \mathrm{mM} \beta$-glycerol phosphate, $1 \mathrm{mM}$ L-phenylalanine, $1 \mathrm{mM}$ sodium orthovanadate, $50 \mathrm{mM}$ sodium fluoride and protease inhibitors $(2 \mu \mathrm{g} / \mathrm{ml}$ pepstatin A, $10 \mu \mathrm{g} / \mathrm{ml}$ leupeptin, $10 \mu \mathrm{g} / \mathrm{ml}$ aprotinin, $4 \mu \mathrm{g} / \mathrm{ml}$ elastinal, $0.5 \mathrm{mg} / \mathrm{ml}$ benzamidine, $1 \mathrm{mM}$ phenylmethanesulfonyl fluoride, $0.4 \mathrm{mM}$ iodoacetic acid, $2.5 \mathrm{mM}$ phenanthroline and $0.1 \mathrm{mM} \quad N$-tosyl-Lphenylalanine chloromethyl ketone (TPCK); all from Sigma). The cells were then homogenized in lysis buffer, placed on ice for $60 \mathrm{~min}$, and then centrifuged for $30 \mathrm{~s}$ at $10000 \mathrm{~g}$ in an Eppendorf benchtop centrifuge. The protein in the supernatant was quantified with BCA protein assay kit (Pierce, Rockford, IL, USA) and stored at $-80{ }^{\circ} \mathrm{C}$. One milligram of lysate protein in $1 \mathrm{ml}$ lysis buffer with protease inhibitors was pre-cleared with $2 \mu \mathrm{l}$ normal rabbit serum (used only for rabbit anti-human CFTR R domain polyclonal antibody; a gift from Dr William Guggino, Department of Medicine, Johns Hopkins University School of Medicine, Baltimore, MD, USA; Zhang et al. 2003). $30 \mu \mathrm{g}$ of protein A-Sepharose (Amersham Bioscience) was added to the samples and incubated at $4{ }^{\circ} \mathrm{C}$ for $2 \mathrm{~h}$, all samples were then centrifuged at $10000 \mathrm{~g}$ to remove nonspecific complexes. Subsequently, $2 \mu$ rabbit polyclonal anti-human CFTR R domain antibody was added and incubated at $4{ }^{\circ} \mathrm{C}$ overnight. To pull down the antigen-antibody complexes, equivalent amounts of protein $\mathrm{A}$ beads were added to each reaction tube and incubated at $4{ }^{\circ} \mathrm{C}$ for $60 \mathrm{~min}$. The antigen-antibody-bead complex was precipitated with a brief spin, and then washed five times for $10 \mathrm{~min}$ each time with $1 \mathrm{ml}$ lysis buffer. The immunoprecipitates were then washed once with $1 \mathrm{ml}$ Tris-buffered saline, $\mathrm{pH} 8 \cdot 0$, and incubated with 5 units of the catalytic subunit of PKA (Sigma) and $10 \mu \mathrm{Ci} \quad\left[\gamma_{-}{ }^{32} \mathrm{P}\right] \mathrm{ATP}$ (NEN-Dupont) in $50 \mu \mathrm{l}$ PKA buffer $(50 \mathrm{mM}$ Tris, $\mathrm{pH}$ $7 \cdot 5,10 \mathrm{mM} \mathrm{MgCl}_{2}$ and $0 \cdot 1 \mathrm{mg} / \mathrm{ml} \mathrm{BSA}$ ) at $30{ }^{\circ} \mathrm{C}$ for $1 \mathrm{~h}$. Following two washes with lysis buffer, the immunoprecipitates were resuspended in $40 \mu \mathrm{L}$ Laemmli sample buffer (Bio-Rad) and incubated at $65^{\circ} \mathrm{C}$ for $4 \mathrm{~min}$. The sample was spun for $2 \mathrm{~min}$ at $8000 \mathrm{~g}$ and the supernatant was either stored at $-20{ }^{\circ} \mathrm{C}$ overnight or loaded directly onto a gel. The proteins were separated on 5\% SDS/polyacrylamide gels (Bio-Rad) and prepared for autoradiography. Exposure time was $30-60 \mathrm{~min}$ at $-70{ }^{\circ} \mathrm{C}$.

\section{Western blotting}

Immunoprecipitation and Western blot analysis were performed for CFTR protein analysis in CaCo-2 cells. After $24 \mathrm{~h}$ with or without stimulation with ANP, cellular protein lysates were obtained and then $200 \mu \mathrm{g}$ total proteins were incubated with a rabbit polyclonal antihuman CFTR R domain antibody (1:1000). The antibody was generated to peptide IEEDSDEPLER RLSLVPDSEQGE, kindly provided by Dr William Guggino (Zhang et al. 2003). Immunoprecipitates were collected with protein A-agarose.

After separating on $7 \cdot 5 \%$ SDS/polyacrylamide gels, proteins were transferred to PVDF membrane (Bio-Rad) in Tris/glycine transfer buffer (Bio-Rad) containing 10\% methanol. The membrane was blocked with 5\% nonfat milk in Tris-buffered saline containing 0.05\% Tween 20 (TTBS) for $1 \mathrm{~h}$ at room temperature and then was incubated overnight with primary antibodies in the blocking buffer. The primary antibody, polyclonal rabbit antihuman CFTR R domain, was diluted 1:1000 for CFTR protein. The membrane was washed three times with TTBS for $10 \mathrm{~min}$ each wash and incubated for $1 \mathrm{~h}$ at room temperature with horseradish peroxidaseconjugated anti-rabbit antibody diluted 1:5000. After washing, the blots were visualized using a standard ECL kit (Amersham Bioscience).

\section{Transient transfections}

The CFTR-promoter reporter plasmid vector construct contained the region from position -2247 to position +52 of the CFTR gene. The plasmid construct was kindly provided by Dr Kelly Mayo, Department of Biochemistry, Northwestern University, Evanston, IL, USA (McDonald et al. 1995). This location contains the major transcription start sites of CFTR (Trapnell et al. 1991).

The CaCo-2 cell line was grown to confluence and on the day before transfection cells were detached by exposure to $0.05 \%$ trypsin in $\mathrm{Ca}^{2+}$ - and $\mathrm{Mg}^{2+}$-free solution, and reseeded in six-well plates to be $90 \%$ confluent on the day of transfection. The cells were transiently cotransfected with $1.5 \mu \mathrm{g}$ CFTR-luc promoter construct plasmid DNA for reporter assays of luciferase and $0.5 \mu \mathrm{g} \mathrm{pSV}-\beta$ galactosidase plasmid (kindly provided by Dr Peter Kopp, Division of Endocrinology, Northwestern University, Chicago, IL, USA) with $6 \mu \mathrm{l}$ LipofectAMINE 2000 reagent (Invitrogen) diluted in $250 \mu \mathrm{l}$ serum- and antibiotic-free DMEM and added to cells in a final volume of $500 \mu \mathrm{l}$ per well. After this the cells were incubated at $37^{\circ} \mathrm{C}$ for $3 \mathrm{~h}$ with the medium mentioned above, after which this medium was removed and $2 \mathrm{ml}$ 
supplemented DMEM were added per well and cells were cultured for $24 \mathrm{~h}$ post-transfection. After this the cells were washed and treated with $10^{-9} \mathrm{M}$ ANP for $24 \mathrm{~h}$ at $37^{\circ} \mathrm{C}$. Cells were washed twice with $3 \mathrm{ml}$ PBS and then lysed in $250 \mu \mathrm{l}$ (per well) with lysis buffer $(25 \mathrm{mM}$

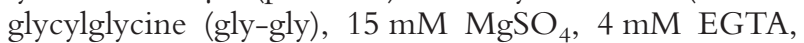
$25 \%$ Triton X100 and $2 \mathrm{mM}$ dithiothreitol) for $20 \mathrm{~min}$ at room temperature. Luciferase activity was quantified using $200 \mu \mathrm{l}$ cell lysates, $100 \mu \mathrm{l}$ D-luciferin (Molecular Probes, Eugene, OR, USA) and $100 \mu \mathrm{l}$ luciferase assay buffer (25 mM gly-gly, $15 \mathrm{mM} \mathrm{MgSO}_{4}$, $4 \mathrm{mM}$ EGTA, $15 \mathrm{mM}$ $\mathrm{KH}_{2} \mathrm{PO}_{4}, 6 \mathrm{mM}$ ATP and $3 \mathrm{mM}$ dithiothreitol) per sample. Light emission was detected using a TD-20/20 Luminometer (Turner Designs, Ann Arbor, MI, USA) for $30 \mathrm{~s}$ at room temperature. $\beta$-Galactosidase activity, used to normalize the results, was quantified using $30 \mu \mathrm{l}$ cell lysates, $160 \mu \mathrm{l}$ 2-Nitrophenyl- $\beta$-D-galactopyranoside (ONPG) reagent $\left(60 \mathrm{mM} \mathrm{Na}_{2} \mathrm{HPO}_{4}, 40 \mathrm{mM} \mathrm{NaH} \mathrm{PO}_{4}\right.$ and $2 \mathrm{mg} / \mathrm{ml} \mathrm{ONPG)}$ and $810 \mu \mathrm{l} \beta$-galactosidase buffer $\left(60 \mathrm{mM} \mathrm{Na} \mathrm{HPO}_{4}, 40 \mathrm{mM} \mathrm{NaH} \mathrm{PO}_{4}, 10 \mathrm{mM} \mathrm{KCl}\right.$, $1 \mathrm{mM} \mathrm{MgCl}_{2}$ and $50 \mathrm{mM} \beta$-mercaptoethanol) at $420 \mathrm{~nm}$.

\section{Statistical analysis}

ANOVA followed by Newman-Keuls multiplecomparison test was used to compare changes in the expression levels of CFTR mRNA between more than three experimental groups. We used an unpaired Student's $t$ test to compare the expression levels of protein between the two different groups in Western blotting, immunoprecipitation followed by phosphorylation and the luciferase assay in $\mathrm{CaCo}-2$ cells. An unpaired Student's $t$-test was also applied to compare the expression levels of CFTR mRNA in rat proximal colon between groups. Results are presented as means \pm S.E Differences were assumed to be significant when $P \leq 0.05$.

\section{Results}

\section{CFTR mRNA modulation by ANP in CaCo-2 cells}

CFTR mRNA modulation in CaCo-2 cells was determined by RPA. Cells treated with different concentrations of ANP $\left(10^{-8}, 10^{-7}\right.$ and $\left.10^{-6} \mathrm{M}\right)$ showed that ANP increases CFTR mRNA expression, and at concentration of $10^{-8} \mathrm{M}$ a maximum effect was reached (44\% increase), when compared with the NT group $(n=4-7, P<0 \cdot 05$; Fig. 1). The CFTR mRNA modulation was also evaluated by semi-quantitative RT-PCR on extracts from cells treated with different concentrations of ANP $\left(10^{-11}\right.$, $10^{-10}, 10^{-9}, 10^{-8}, 10^{-7}$ and $\left.10^{-6} \mathrm{M}\right)$. CFTR mRNA expression increased $74 \%(n=8, P<0001)$ and $54 \%(n=8$, $P<0 \cdot 01)$ compared with the control group when cells were treated with ANP at $10^{-9} \mathrm{M}$ (maximum effect) and $10^{-8} \mathrm{M}$ respectively (Fig. 2). The mRNA expression of

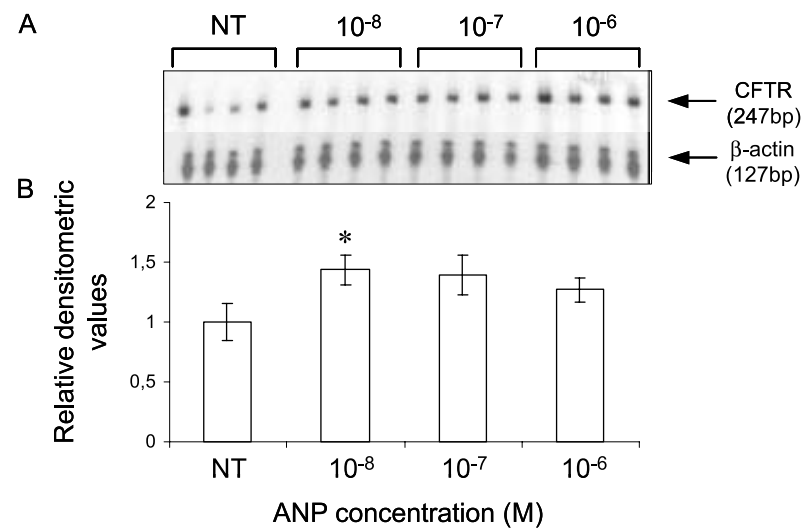

Figure 1 RPA for CFTR in Caco-2 cells. (A) Representative RPA results of CFTR (247 bp) and $\beta$-actin (125 bp) mRNA expression. Bands were obtained by hybridization of CFTR or $\beta$-actin probes and $30 \mu \mathrm{g}$ total RNA extracted from CaCo-2 cells treated with ANP peptide at different concentrations. $\beta$-Actin with less exposure to the X-ray films ( $6 \mathrm{~h}$ ) was utilized to normalize the experiments (indicated by arrow at $127 \mathrm{bp}$; the upper band). (B) Graphic representation of the means \pm S.E. for the ratio between densitometric values of CFTR and $\beta$-actin $(n=4-7, P<0 \cdot 05)$.

CFTR analyzed by RT-PCR in cells treated at $10^{-8}$, $10^{-7}$ and $10^{-6} \mathrm{M}$ ANP demonstrated similar results to those observed using RPA. Using RT-PCR, we could also show the presence of NPR-A, NPR-B and NPR-C mRNA in CaCo-2 cells (Fig. 3).

ANP treatment increases the mature and immature forms of CFTR in CaCo-2 cells using immunoprecipitation/ phosphorylation

The immature form of CFTR, representing CFTR located in the endoplasmic reticulum, is a core-glycosylated protein that is sensitive to endoglycosidase $\mathrm{H}$ (band $\mathrm{B}$ ). The fully glycosylated, endoglycosidase H-resistant CFTR protein is about $20-30 \mathrm{kDa}$ larger than the coreglycosylated CFTR, and represents the mature form of CFTR (band C) that is localized in the post-endoplasmic reticulum compartments, including the plasma membrane. The CaCo-2 cell line showed mainly the fully glycosylated (band C) form of this protein, consistent with expression of mature form of CFTR. CFTR band C had an increase of approximately 5 -fold in cells treated with $10^{-9} \mathrm{M}$ ANP for $24 \mathrm{~h}$, compared with the NT group $(n=4, P<0 \cdot 05$; Fig. 4). We also observed an increase in the CFTR band B, the immature form of CFTR, by approximately 4-fold in cells treated with $10^{-9} \mathrm{M}$ ANP $(n=4$, $P<0 \cdot 05$; Fig. 4). No other unspecific bands were observed in the blot.

CFTR protein expression modulation in $\mathrm{CaCo}-2$ cells by ANP using immunoprecipitation followed by Western blot

Plasma membrane proteins were extracted from $\mathrm{CaCo}-2$ cells after incubation with $10^{-9} \mathrm{M}$ ANP for $24 \mathrm{~h}$, 


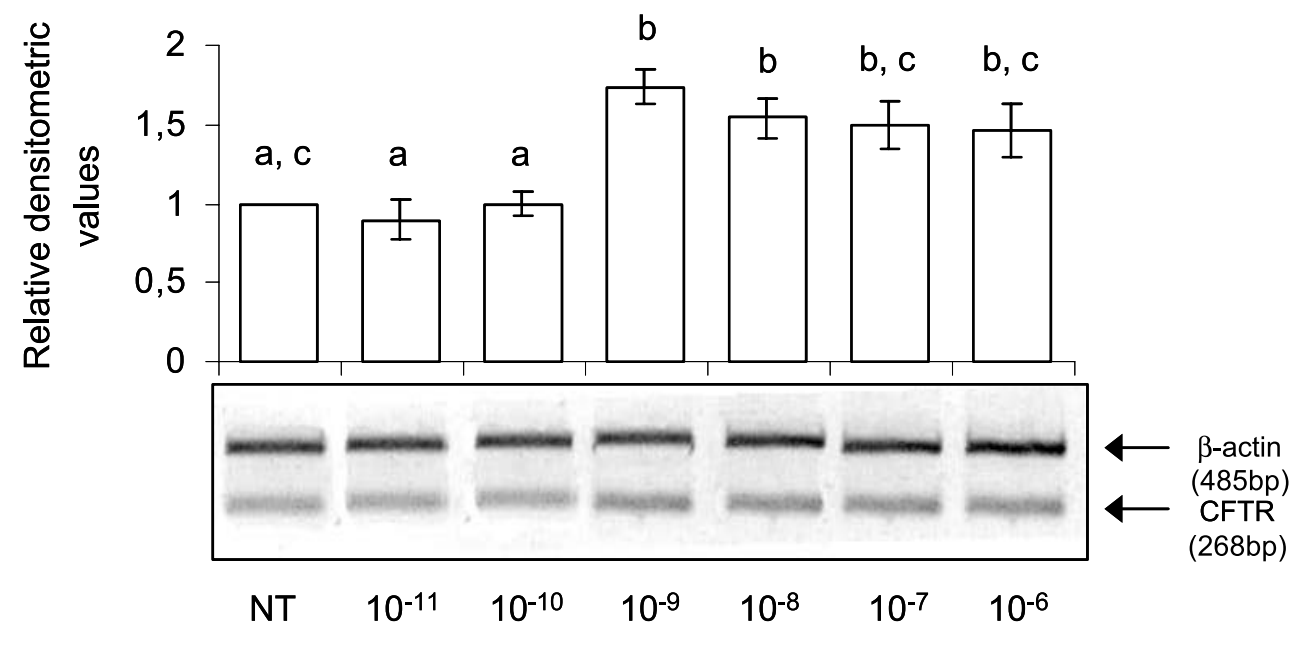

ANP concentration (M)

Figure 2 Examination of CFTR mRNA expression modulation by ANP in CaCo-2 cells by semi-quantitative RT-PCR. Representative 1.5\% agarose gel of CFTR (268 bp) and $\beta$-actin (485 bp) genes semi-quantitative RT-PCR, and graphic representation of the means \pm S.E. for the ratio between densitometric values of CFTR and $\beta$-actin $(n=5-8, P<0 \cdot 01)$. There is no statistical difference between groups with the same letters (ANOVA followed by Newman-Keuls test).

a concentration which promoted maximum modulation of CFTR mRNA (result obtained on RPA and RT-PCR experiments). Densitometric analysis of CFTR protein, obtained by immunoprecipitation followed by Western blot, demonstrated an increase of about 4-fold in CFTR protein expression in cells treated with ANP compared with NT cells $(n=4, P<0 \cdot 01$; Fig. 5$)$. Only band C of CFTR (the most abundant form) was detected using this technique.

CFTR gene expression modulation by cGMP action in $\mathrm{CaCo}-2$ cells

In CaCo-2 cells, semi-quantitative RT-PCR was performed to evaluate CFTR mRNA modulation by cGMP (an intracellular ANP-related second messenger). CaCo-2 cells treated with cGMP $(1 \mathrm{mM})$ and also cells treated with both ANP $\left(10^{-9} \mathrm{M}\right)$ and cGMP $(1 \mathrm{mM})$ showed an increase of CFTR mRNA expression, compared with the NT group, of $93 \%(n=4, P<0 \cdot 001)$ and $88 \%(n=3$, $P<0 \cdot 01)$, respectively. No statistical difference was observed in cells treated with both ANP and $5 \mu \mathrm{M}$ cGMPI $(n=4)$ when compared with the NT group. In cells treated with both cGMP and cGMPI or cells treated only with cGMPI there was no difference in CFTR mRNA expression when compared with the NT group $(n=4$; Fig. 6).

Modulation of CFTR chloride channel gene promoter region by ANP in CaCo-2 cells

To examine potential regulation of the CFTR promoter by ANP, a $2 \cdot 2 \mathrm{~kb}$ fragment of the human CFTR promoter was ligated to a luciferase reporter gene (CFTR-luc) and a luciferase assay was performed. Luciferase activity is a common way to show stimulation of a gene-promoter region (McDonald et al. 1995, Trapnell et al. 1991). In transient transfection of CaCo-2 cells with CFTR-luc we observed a $24 \%$ increase in luciferase activity when cells were treated with ANP $\left(10^{-9} \mathrm{M}\right)$, compared with cells transfected with the same plasmid but without ANP treatment $(n=5, P<0 \cdot 01)$. This result shows that ANP has the ability to activate, directly or indirectly, a segment of the CFTR promoter region (Fig. 7).

\section{CFTR $m R N A$ modulation in rats subjected to volume expansion or intravenous infusion of $A N P$}

The CFTR mRNA modulation was also evaluated by semi-quantitative RT-PCR in rats subjected to volume expansion with $0.9 \%$ saline intravenous infusion. We showed that in rat proximal colon acute extracellular volume expansion leads to an increase of CFTR mRNA expression in $60 \%$ of control group values $(n=3, P<0 \cdot 001$; Fig. 8A). Furthermore, rats subjected to continuous intravenous infusion of synthetic ANP showed that CFTR mRNA expression increased $50 \%$ over control group values $(n=6, P<0001$; Fig. $8 \mathrm{~B})$.

\section{Discussion}

Ion transport is essential for intestinal function. The absorption of water in the intestine, and also in the kidney, is a process secondary to solute absorption, mainly by $\mathrm{Na}^{+}$ 


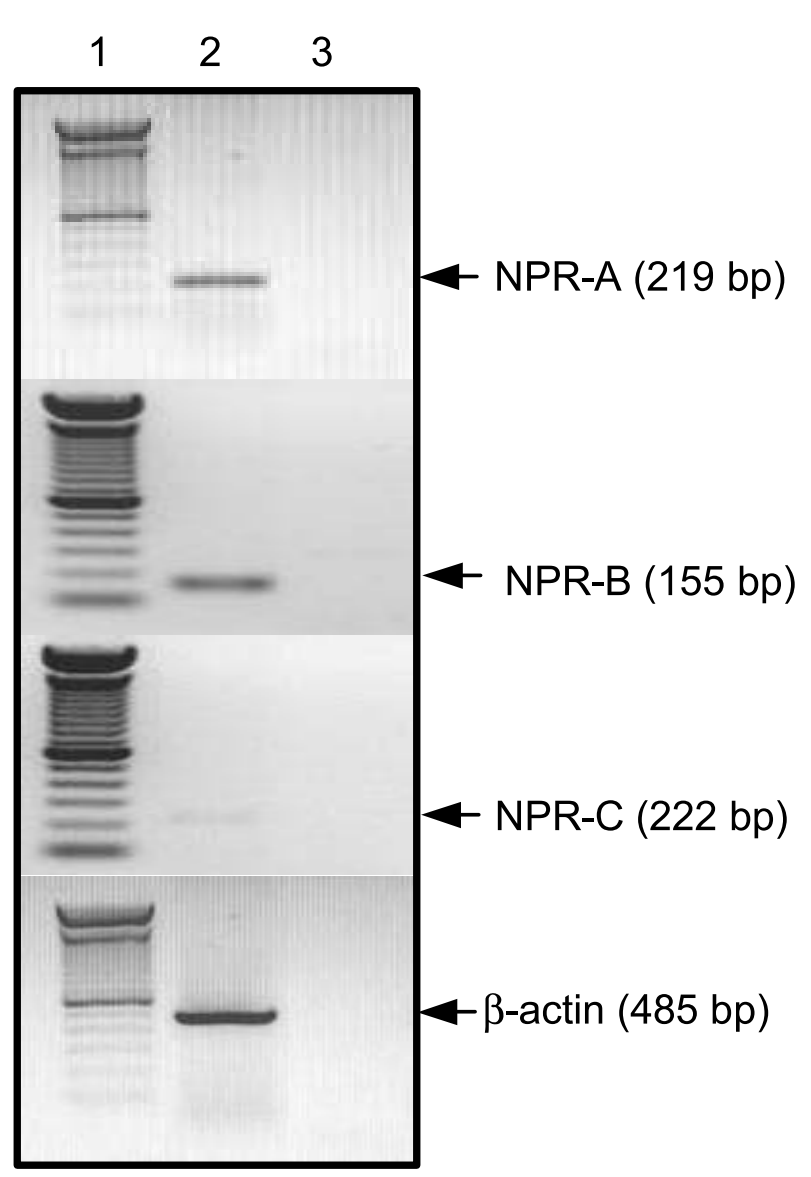

Figure 3 Detection of mRNAs for natriuretic peptide receptors in CaCo-2 cells by RT-PCR. Representative $1.5 \%$ agarose gel of NPR-A (219 bp), NPR-B (155 bp), NPR-C (222 bp) and $\beta$-actin (485 bp) RT-PCR products. Lanes 1, $100 \mathrm{bp}$ molecular mass ladder; lanes 2, CaCo-2 cells; lanes 3, RT( - ) control.

and $\mathrm{Cl}^{-}$, the most abundant ions in the extracellular medium. In the first portion of the intestine (the small intestine) the absorption of $\mathrm{NaCl}$ is approximately $90 \%$. It is also known that about $90 \%$ of water ingested reaches this part of the gastrointestinal tract. Around 1.5 1 of water reaches the distal portion of the intestine (colon) daily, and only $100 \mathrm{ml}$ is excreted in the feces (Turnberg 1984). The colon has the capacity to absorb 4-61 of fluid daily (Sanioto 1999, Johnson 1997).

In pathological cases, for example, the heat-stable Escherichia coli toxin leads to inhibition of $\mathrm{Na}^{+}$absorption, as well an increase of $\mathrm{Cl}^{-}$secretion. The accumulation of $\mathrm{NaCl}$ in the intestinal lumen reduces water absorption and generates a diarrhea-inducing effect in the small intestine (Field \& Semrad 1993, Rolfe 1999). Several hormones and autacoids can also alter the intestinal function through action on the expression and/or activity of ion transporters, mainly in colon (Binder \& Sandle 1994). The action of hormonal secretagogues, such as aldosterone, ANP and
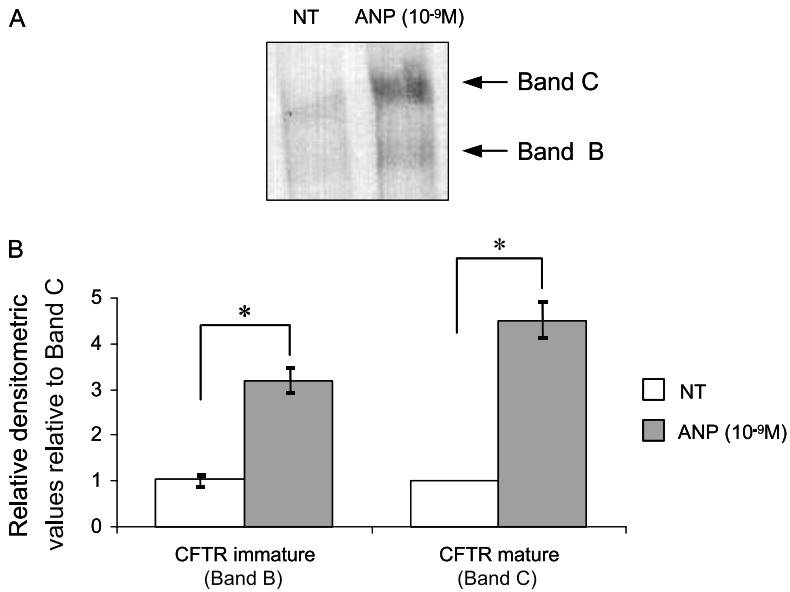

Figure 4 Immunoprecipitation followed by in vitro phosphorylation from CaCo-2 cells. (A) Representative immunoprecipitation/phosphorylation results of CFTR mature form (band C) and CFTR immature form (band B). Lane 1, NT cells; lane 2, cells treated with $10^{-9} \mathrm{M}$ ANP. (B) Graphic representation of means \pm s.E. for the ratio between densitometric values of CFTR immature and mature forms relative to CFTR band $C(n=4, P<0 \cdot 05)$.

autacoids, for example prostaglandins, are important for maintenance of normal intestinal tract physiology (Field \& Semrad 1993).

The physiological role of CFTR in the intestinal epithelia has been more evident in studies carried out in CFTR-knockout mice. These animals, even when they are heterozygotes for mutations in the CFTR gene,

A

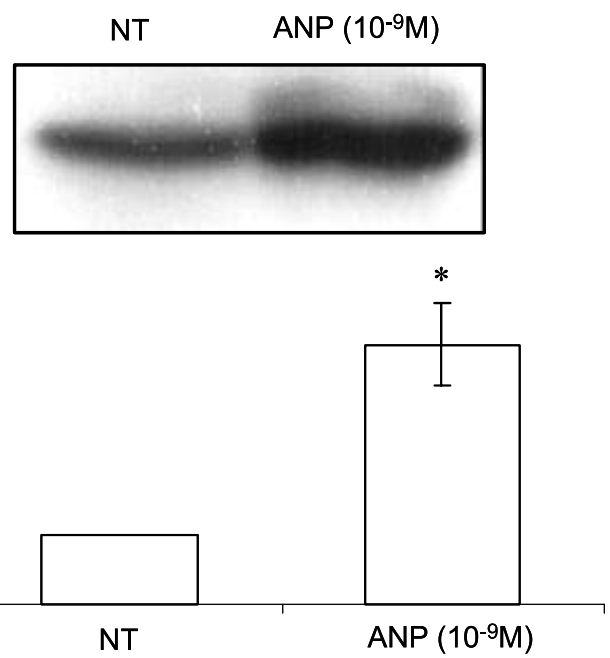

Figure 5 Detection of CFTR protein by immunoprecipitation and Western blot analysis in CaCo-2 cells. (A) Representative immunoblot for CFTR in membrane extracts prepared from CaCo-2 cells. Lane 1, NT cells; lane 2 , cells treated with $10^{-9} \mathrm{M}$ ANP. (B) Graphic representation of means \pm S.E. for densitometric values of CFTR protein bands obtained in the Western blot experiments $(n=3, P<0 \cdot 05)$. 


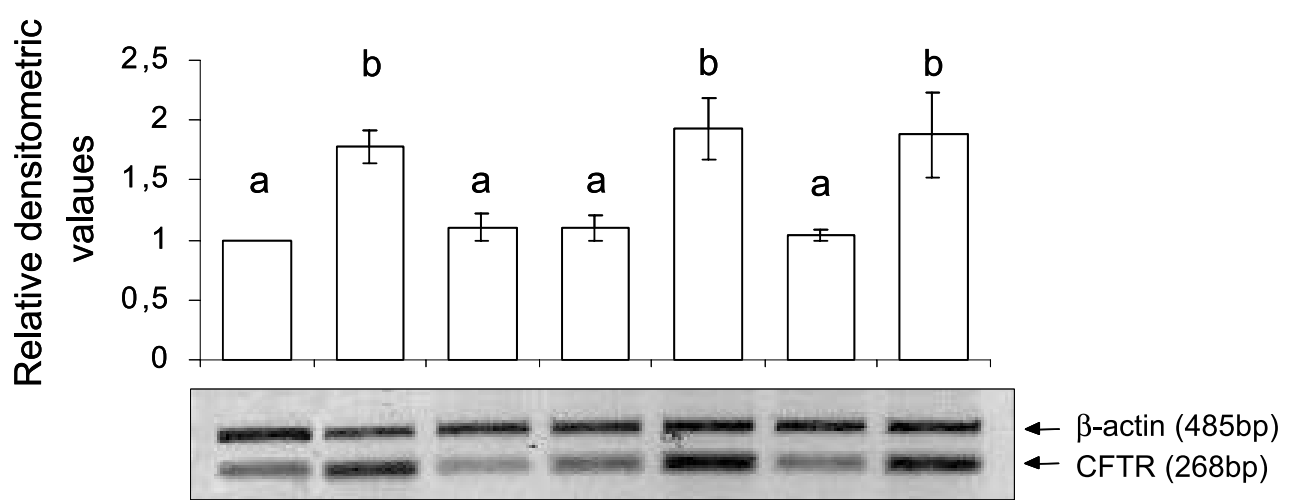

Figure 6 CFTR mRNA expression modulation by cGMP in CaCo-2 cells (semi-quantitative RT-PCR). Agarose gel representative of semi-quantitative RT-PCR of CFTR (268 bp) and $\beta$-actin (485 bp) genes, and graphic representation of the means \pm S.E. from the ratio between densitometric values of CFTR and $\beta$-actin. Lane 1, NT cells; lane 2, cells treated with ANP; lane 3, cells treated with ANP+cGMPI; lane 4, cells treated with cGMP+cGMPI; lane 5, cells treated with cGMP; lane 6, cells treated with cGMPI; lane 7, cells treated with ANP+cGMP. ANP $\left(10^{-9} \mathrm{M}\right)$, cGMP $(1 \mathrm{mM})$, cGMPI $(5 \mu \mathrm{M})$. There is no statistical difference between groups with the same letters $(n=4, P<0 \cdot 01$; ANOVA followed by Newman-Keuls test).

do not respond completely to the effects of the secretagogues compared with normal animals (Grubb \& Boucher 1999). It is a fact that most of these mice die from intestinal complications, which clearly indicate the crucial role of CFTR in these epithelia (Snouwaert et al. 1992, Eckman et al. 1995).

During extracellular volume expansion, changes in the plasma concentration of several hormones occurs. In this situation, for example, while aldosterone and angiotensin concentrations are decreased at plasma levels, the ANP concentration is increased. As has been largely reported, the intestinal tract is a target organ for ANP. ANP in the small intestine was found to reduce the reabsorption of water, $\mathrm{Na}^{+}$and dextrose in rats (Martinez Seeber et al. 1986). In dogs, Matsushita et al. (1991) demonstrated that ANP suppressed the reabsorption not only of water and $\mathrm{Na}^{+}$, but also $\mathrm{Cl}^{-}$across the jejunum. In the large intestine

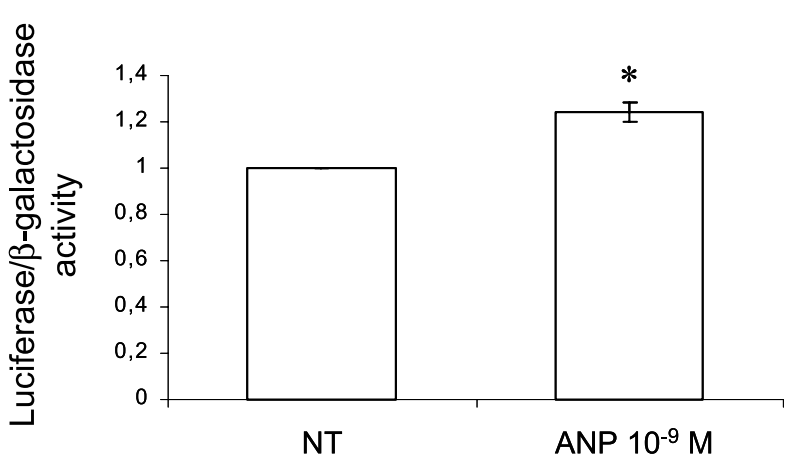

Figure 7 Modulation of CFTR chloride-channel gene-promoter region in $\mathrm{CaCo}-2$ cells by ANP. Shows the luciferase activities in CaCo-2 for the NT group and cells treated with $10^{-9} \mathrm{M}$ ANP. Luciferase activities were normalized by cotransfection with the pSV- $\beta$-galactosidase plasmid. Means \pm S.E. are shown $(n=4, P<0 \cdot 01)$.
ANP causes a transient increase in potential differences and a short-circuit current across the proximal and distal colon mounted in Ussing chambers (Argenzio \& Armstrong 1993, Moriarty et al. 1990, Vaandrager et al. 1992), suggesting ANP's involvement in ion transport in this tissue. However, these changes were not observed in the human colonic cell line T84 (human colonic carcinoma derived from metastasis in the lung), which has different characteristics to $\mathrm{CaCo}-2$ cells.

Acting directly or indirectly it is suggested that the hormone-sensitive chloride channels at the apical membranes of epithelial cells provide well-characterized mechanisms that control epithelial cell conductance and, because it was shown previously that ANP's effects in rat colon are both chloride-dependent and sensitive to chloride-channel blockers, this channel is probably one of ANP's ultimate molecular targets in the colon (Moriarty et al. 1990). CFTR could be that chloride channel once it is expressed in colon, and could control the conductance of other ions.

In our experiments, the animals subjected to extracellular volume expansion showed a $60 \%$ increase of CFTR mRNA expression in proximal colon compared with control animals. This increase was probably related to the ANP plasma concentration enhancement, as we also observed a similar rate of increase (50\% of CFTR mRNA expression) in proximal colon of rats subjected to continuous intravenous infusion with synthetic ANP.

In vitro, using $\mathrm{CaCo}-2$ cells as a model, $\mathrm{ANP}$ is able to increase the expression of the CFTR mRNA with maximum stimulation observed at $10^{-9} \mathrm{M}$, the physiological basal plasma level of ANP found in humans (Ando et al. 1990, Sagnella 1998). This stimulation was statistically similar to cells treated with ANP at $10^{-8}, 10^{-7}$ and $10^{-6} \mathrm{M}$, which is the same pattern observed in other 

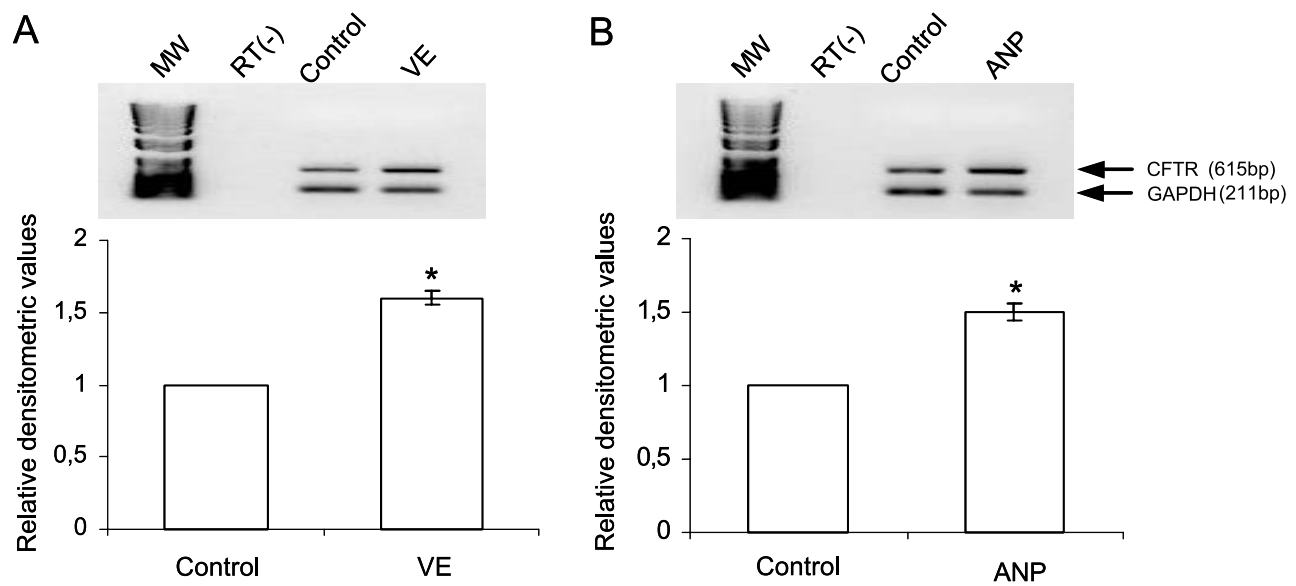

Figure 8 CFTR mRNA expression modulation in proximal colon of rats subjected to extracellular volume expansion or ANP intravenous infusion. Agarose gel representative of semi-quantitative RT-PCR of CFTR (615 bp) and GAPDH (211 bp) genes. Graphical representation of means \pm s.E. from the ratio between densitometric values of CFTR and GAPDH. (A) Animals subjected to extracellular volume expansion (VE) and control group (Control; $n=3, P<0001$ ). (B) Animals treated with synthetic ANP (ANP) and control group $(n=6, P<0001)$. MW: molecular mass ladder; $\mathrm{RT}(-)$ ): negative control without RT.

studies such as for the heme oxygenase-1 (HO-1) gene (Kiemer et al. 2003).

In CaCo-2 cells we observed that CFTR mRNA expression was increased $74 \%$ when compared with NT cells. In the same way CFTR protein was found to be increased in cells treated with $10^{-9} \mathrm{M}$ ANP of approximately 5-fold for the mature form of CFTR (functional protein) and approximately 4-fold for the immature form of CFTR protein (non-functional protein). The greater stimulation at the protein level compared with the mRNA level suggests a possible post-transcriptional action of ANP.

It is important to mention that ANP's half-life is 2-5 min, but this action leads to several changes at the cellular level (second messengers, expression of transcriptional factors, etc.) that could change gene expression at both the mRNA and protein levels (Wolf et al. 1995). Three receptors are related to different natriuretic peptides. NPR-A binds ANP with specificity and high affinity. It was suggested that NPR-B may be relatively more selective for brain natriuretic peptide than for ANP when compared with NPR-A (Takayanagi et al. 1987). The NPR-C binds ANP with high affinity, and it is involved in the sequestration and metabolic clearance of ANP. It was suggested that NPR-C is coupled to the adenylate cyclase/cAMP signal transduction pathways (Anand-Srivastava \& Trachte 1993). In our results we showed high abundance of NPR-A and NPR-B in $\mathrm{CaCo}-2$ cells but the involvement of each receptor in the CFTR expression stimulation must still be clarified. The ANP binding to NPR-A and NPR-B produces an increase in cGMP in several types of tissue, including colonic cells. It was shown previously that the enhanced cGMP in cells induces phosphorylation of different proteins that can lead to a stimulation or inhibition of activity (Gonzalez Bosc et al. 2000, Lin et al. 1992). In addition, it was shown that cGMP is involved in control of gene expression via its action on different gene-promoter regions or by controlling the activities of transcription factors such as AP-1, c-Jun N-terminal kinase and extracellular-signal-regulated kinase (Kiemer et al. 2003, Pilz \& Casteel 2003). Acting in these two ways the cGMP could control gene expression. Our results showed that cGMP increases CFTR mRNA expression in CaCo-2 cells, in the same manner observed when ANP is used without cGMP addition. Furthermore, ANP and cGMP together did not have cumulative effects on CFTR mRNA expression. These results suggest that ANP acts via cGMP in CaCo-2 cells, leading to the modulation of CFTR. On the other hand, we cannot discard the possibility that cGMP might be acting through the inhibition of phosphodiesterases, permitting an increase of cAMP levels, the second messenger that is also capable of activating CFTR chloride-channel conductance and its gene expression (McDonald et al. 1995), enhancing the action of cGMP. Experiments are necessary to clarify the functional significance of the stimulation of expression CFTR by ANP.

The in vitro model also helped to observe that ANP stimulates the CFTR promoter region, suggesting that the modulation of CFTR expression through ANP action in $\mathrm{CaCo}-2$ cells could be secondary to the increase of gene transcription. However, the posttranscriptional regulatory effects of this hormone cannot be discarded.

In conclusion, the present study is the first to directly access the effect of ANP on CFTR expression in proximal colon of rats and in $\mathrm{CaCo}-2$ cells suggesting that this 
peptide has a physiological importance in ion transport in the gastrointestinal tract.

\section{Acknowledgements}

The present work was supported by grants from Conselho Nacional de Desenvolvimento Científico e Tecnológico (CNPq), Financiadora de Estudos e Projetos (FINEP) e Programa de Apoio aos Núcleos de Excelência (PRONEX), Third World Academy of Sciences (TWAS), Instituto do Milênio and Fundação Carlos Chagas Filho de Amparo a Pesquisa do Estado do Rio de Janeiro (FAPERJ). The authors declare that there is no conflict of interest that would prejudice the impartiality of this scientific work.

\section{References}

Anand-Srivastava MB \& Trachte GJ 1993 Atrial natriuretic factor receptors and signal transduction mechanisms. Pharmacological Reviews 45 455-497.

Ando K, Hirata Y, Emori T, Shichiri M, Kurosawa T, Sato K \& Marumo FJ 1990 Circulating forms of human atrial natriuretic peptide in patients with congestive heart failure. Clinical Endocrinology \& Metabolism 70 1603-1607.

Argenzio RA \& Armstrong M 1993 ANP inhibits NaCl absorption and elicits $\mathrm{Cl}^{-}$secretion in porcine colon: evidence for cGMP and $\mathrm{Ca}^{++}$mediation. American Journal of Physiology Regulatory, Integrative and Comparative Physiology 265 R57-R65.

Binder HJ \& Sandle GI 1994 Electrolyte transport in the mammalian colon. In Physiology of the Gastrointestinal Tract, edn 3, pp 2133-2171. Ed LR Johnson. New York, NY, USA: Raven.

Chang EB, Bookstein C, Vaandrager A, DeJonge HR, Buse J \& Musch MW 1991 Cystic fibrosis transmembrane regulator mRNA expression relative to ion-nutrient transport in spontaneously differentiating human intestinal $\mathrm{CaCo}-2$ epithelial cells. Journal of Laboratory Clinical Medicine 118 377-381.

Cheng SH, Gregory RJ, Marshall J, Paul S, Souza DW, White GA, O'Riordan CR \& Smith AE 1990 Defective intracellular transport and processing of CFTR is the molecular basis of most cystic fibrosis. Cell 63 827-834.

Coric T, Hernandez N, de la Rosa DA, Shao D, Wang T \& Canessa CM 2004 Expression of ENaC and serum- and glucocorticoid-induced kinase 1 in the rat intestinal epithelium. American Journal of Physiology Gastrointestinal and Liver Physiology 286 G663-G670.

Crawford I, Maloney PC, Zeitlin PL, Guggino WB, Hyde SC, Turley H, Gatter KC, Harris A \& Higgins CF 1991 Immunocytochemical localization of the cystic fibrosis gene product CFTR. PNAS 88 9262-9266.

Denning GM, Anderson MP, Amara JF, Marshall J, Smith AE \& Welsh MJ 1992 Processing of mutant cystic fibrosis transmembrane conductance regulator is temperature-sensitive. Nature 358 761-764.

Dietz JR 1984 Release of natriuretic factor from rat heart-lung preparation by atrial distension. American Journal of Physiology Regulatory, Integrative and Comparative Physiology 247 R1093-R1096.

Dietz JR 1987 Control of atrial natriuretic factor release from a rat heart-lung preparation. American Journal of Physiology Regulatory, Integrative and Comparative Physiology 252 R498-R502.

Dunn BR, Ichikawa I, Pfeffer JM, Troy JL \& Brenner BM 1986 Renal and systemic hemodynamic effects of synthetic atrial natriuretic peptide in the anesthetized rat. Circulation Research $59237-246$.
Ecke D, Bleich M \& Greger R 1996 The amiloride inhibitable $\mathrm{Na}^{+}$ conductance of rat colonic crypt cells is suppressed by forskolin. Pflugers Archiv 431 984-986.

Eckman EA, Cotton CU, Kube DM \& Davis PB 1995 Dietary changes improve survival of CFTR S489X homozygous mutant mouse. American Journal of Physiology Lung Cellular and Molecular Physiology 269 L625-L630.

Ehrenreich H, Sinowatz F, Schulz R, Arendt RM \& Goebel FD 1989 Immunoreactive atrial natriuretic peptide (ANP) in endoscopic biopsies of the human gastrointestinal tract. Respiratory Experimental Medicine (Berlin) 189 421-425.

Estevez R, Boettger T, Stein V, Birkenhager R, Otto E, Hildebrandt F \& Jentsch TJ 2001 Barttin is a $\mathrm{Cl}^{-}$channel beta-subunit crucial for renal $\mathrm{Cl}^{-}$reabsorption and inner ear $\mathrm{K}^{+}$secretion. Nature $414558-561$.

Field M \& Semrad CE 1993 Toxigenic diarrheas, congenital diarrheas, and cystic fibrosis: disorders of intestinal ion transport. Annual Reviews in Physiology 55 631-655.

Gaillard D, Ruocco S, Lallemand A, Dalemans W, Hinnrasky J \& Puchelle E 1994 Immunohistochemical localization of cystic fibrosis transmembrane conductance regulator in human fetal airway and digestive mucosa. Pediatric Research 36 137-143.

Gonzalez Bosc LV, Majowicz MP \& Vidal NA 2000 Effects of atrial natriuretic peptide in the gut. Peptides 21 875-887.

Grasset E, Bernabeu J \& Pinto M 1985 Epithelial properties of human coloniccarcinoma cell line Caco-2: effect ofsecretagogues. American Journal of Physiology Cell Physiology 248 C410-C418.

Gregory RJ, Cheng SH, Rich DP, Marshall J, Paul S, Hehir K, Ostedgaard L, Klinger KW, Welsh MJ \& Smith AE 1990

Expression and characterization of the cystic fibrosis transmembrane conductance regulator. Nature 347 382-386.

Grotjohann I, Schulzke JD \& Fromm M 1999 Electrogenic Na ${ }^{+}$ transport in rat late distal colon by natural and synthetic glucocorticosteroids. American Journal of Physiology Gastrointestinal and Liver Physiology 276 G491-G498.

Grubb BR \& Boucher RC 1999 Pathophysiology of gene-targeted mouse models for cystic fibrosis. Physiology Reviews 79 S193-S214.

Jentsch TJ, Stein V, Weinreich F \& Zdebik AA 2002 Molecular structure and physiological function of chloride channels. Physiology Reviews 82 503-568.

Johnson LR 1997 Fluid and electrolyte absorption. In Gastrointestinal Physiology, edn 5, pp 135-145. Eds LR Johnson \& TA Gerwin. St Louis, MO, USA: Mosby.

Kato J, Kida O, Higa T, Sasaki A, Kondo K, Miyata A, Kangawa K, Matsuo H \& Tanaka K 1986 Increase in plasma atrial natriuretic polypeptide (ANP) following sodium load in anesthetized rats. Life Science 39 493-497.

Kiemer AK, Bildner N, Weber NC \& Vollmar AM 2003 Characterization of heme oxygenase 1 (heat shock protein 32) induction by atrial natriuretic peptide in human endothelial cells. Endocrinology 144 802-812.

Kunzelmann K \& Mall M 2002 Electrolyte transport in the mammalian colon: mechanisms and implications for disease. Physiology Reviews 82 245-289.

Lin M, Nairn AC \& Guggino SE 1992 cGMP-dependent protein kinase regulation of a chloride channel in T84 cells. American Journal of Physiology Cell Physiology 262 C1304-C1312.

Maack T 1996 Role of atrial natriuretic factor in volume control. Kidney International 49 1732-1737.

Mall M, Bleich M, Kuehr J, Brandis M, Greger R \& Kunzelmann K 1999 CFTR-mediated inhibition of epithelial $\mathrm{Na}^{+}$conductance in human colon is defective in cystic fibrosis. American Journal of Physiology Gastrointestinal and Liver Physiology 277 G709-G716.

Martinez Seeber A, Vidal NA, Carchio SM \& Karara AL 1986 Inhibition of water-sodium intestinal absorption by an atrial extract. Canadian Journal of Physiology \& Pharmacology 64 244-247. 
Matsushita K, Nishida Y, Hosomi H \& Tanaka S 1991 Effects of atrial natriuretic peptide on water and $\mathrm{NaCl}$ absorption across the intestine. American Journal of Physiology Regulatory, Integrative and Comparative Physiology 260 R6-R12.

McCray Jr PB, Reenstra WW, Louie E, Johnson J, Bettencourt JD \& Bastacky J 1992 Expression of CFTR and presence of cAMPmediated fluid secretion in human fetal lung. American Journal of Physiology Lung Cellular and Molecular Physiology 262 L472-L481.

McDonald RA, Matthews RP, Idzerda RL \& McKnight GS 1995 Basal expression of the cystic fibrosis transmembrane conductance regulator gene is dependent on protein kinase A activity. PNAS 92 7560-7564.

Morales MM, Nascimento DS, Capella MA, Lopes AG \& Guggino WB 2001 Arginine vasopressin regulates CFTR and ClC-2 mRNA expression in rat kidney cortex and medulla. Pflugers Archiv 443 202-211.

Moriarty KJ, Higgs NB, Lees M, Tonge A, Wardle TD \& Warhurst G 1990 Influence of atrial natriuretic peptide on mammalian large intestine. Gastroenterology 98 647-653.

Nilius B \& Droogmans G 2003 Amazing chloride channels: an overview. Acta Physiologica Scandinavica 177 119-147.

O’Loughlin EV, Hunt DM, Gaskin KJ, Stiel D, Bruzuszcak IM, Martin HC, Bambach C \& Smith R 1991 Abnormal epithelial transport in cystic fibrosis jejunum. American Journal of Physiology Gastrointestinal and Liver Physiology 260 G758-G763.

Ornellas DS, Nascimento DS, Christoph DH, Guggino WB \& Morales MM 2002 Aldosterone and high- $\mathrm{NaCl}$ diet modulate ClC-2 chloride channel gene expression in rat kidney. Pflugers Archiv 444 193-201.

Pilz RB \& Casteel DE 2003 Regulation of gene expression by cyclic GMP. Circulation Research 93 1034-1046.

Riordan JR, Rommens JM, Kerem B, Alon N, Rozmahel R, Grzelczak Z, Zielenski J, Lok S, Plavsic N \& Chou JL 1989 Identification of the cystic fibrosis gene: cloning and characterization of complementary DNA. Science 245 1066-1073.

Rolfe V 1999 Colonic fluid and electrolyte transport in health and disease. Veterinary Clinics of North America Small Animal Practice 29 577-588.

Sagnella GA 1998 Measurement and significance of circulating natriuretic peptides in cardiovascular disease. Clinical Science (London) 95 519-529.

Sanioto SML 1999 Absorção intestinal. In Fisiologia, edn 2, pp 689-738. Ed MM Aires. Rio de Janeiro, Brazil: Guanabara Koogan.

Santos Ornellas D, Grozovsky R, Goldenberg RC, Carvalho DP, Fong P, Guggino WB \& Morales M 2003 Thyroid hormone modulates ClC-2 chloride channel gene expression in rat renal proximal tubules. Journal of Endocrinology 178 503-511.

Schroeder BC, Waldegger S, Fehr S, Bleich M, Warth R, Greger R \& Jentsch TJ 2000 A constitutively open potassium channel formed by KCNQ1 and KCNE3. Nature 403 196-199.

Schulman G, Lindemeyer R, Barman A, Karnik S \& Bastl CP 1996 Atrial natriuretic peptide inhibits mineralocorticoid receptor function in rat colonic surface cells. Journal of Clinical Investigations 98 157-166.
Schwiebert EM, Egan ME, Hwang TH, Fulmer SB, Allen SS, Cutting GR \& Guggino WB 1995 CFTR regulates outwardly rectifying chloride channels through an autocrine mechanism involving ATP. Cell 81 1063-1073.

Snouwaert J, Brigman KK, Latour AM, Malouf NN, Boucher RC, Smithies O \& Koller BH 1992 An animal model for cystic fibrosis made by gene targeting. Science 257 1083-1088.

Sood R, Bear C, Auerbach W, Reyes E, Jensen T, Kartner N, Riordan JR \& Buchwald M 1992 Regulation of CFTR expression and function during differentiation of intestinal epithelial cells. EMBO Journal 11 2487-2494.

Strong TV, Boehm K \& Collins FS 1994 Localization of cystic fibrosis transmembrane conductance regulator mRNA in the human gastrointestinal tract by in situ hybridization. Journal of Clinical Investigations 93 347-354.

Stutts MJ, Canessa CM, Olsen JC, Hamrick M, Cohn JA, Rossier BC \& Boucher RC 1995 CFTR as a cAMP-dependent regulator of sodium channels. Science 269 847-850.

Takayanagi R, Snajdar RM, Imada T, Tamura M, Pandey KN, Misono KS \& Inagami T 1987 Purification and characterization of two types of atrial natriuretic factor receptors from bovine adrenal cortex: guanylate cyclase-linked and cyclase-free receptors. Biochemical \& Biophysical Research Communications 144 244-250.

Trapnell BC, Zeitlin PL, Chu CS, Yoshimura K, Nakamura H, Guggino WB, Bargon J, Banks TC, Dalemans W \& Pavirani A 1991 Down-regulation of cystic fibrosis gene mRNA transcript levels and induction of the cystic fibrosis chloride secretory phenotype in epithelial cells by phorbol ester. Journal of Biological Chemistry 266 10319-10323.

Turnberg LA 1984 Mechanisms of control of intestinal transport: a review. Journal of the Royal Society of Medicine 77 501-505.

Vaandrager AB, Bot AG, De Vente J \& De Jonge HR 1992 Atriopeptins and Escherichia coli enterotoxin STa have different sites of action in mammalian intestine. Gastroenterology 102 1161-1169.

Vuolteenaho O, Arjamaa O, Vakkuri O, Maksniemi T, Nikkila L, Kangas J, Puurunen J, Ruskoaho H \& Leppaluoto J 1988 Atrial natriuretic peptide (ANP) in rat gastrointestinal tract. FEBS Letters 233 79-82.

Waldman SA, Rapoport RM \& Murad F 1984 Atrial natriuretic factor selectively activates particulate guanylate cyclase and elevates cyclic GMP in rat tissues. Journal of Biological Chemistry 259 14332-14334.

Wolf G, Ziyadeh FN \& Stahl RA 1995 Atrial natriuretic peptide stimulates the expression of transforming growth factor-beta in cultured murine mesangial cells: relationship to suppression of proliferation. Journal of the American Society of Nephrology 6 224-233.

Zhang XM, Wang XT, Yue H, Leung SW, Thibodeau PH, Thomas PJ \& Guggino SE 2003 Organic solutes rescue the functional defect in delta F508 cystic fibrosis transmembrane conductance regulator. Journal of Biological Chemistry 278 51232-51242.

Received in final form 10 January 2006 Accepted 16 January 2006 